\title{
Effect of Some Anti-Senescence Compounds on the Postharvest Quality and longevity of Cut Cyperus alternifolius Stems
}

\author{
Rehab A. Soffar and Asmaa M. Taha \\ Antoniades Research Branc.Ornamental Plants Research and Landscape, Gardening, \\ Alexandria,Horticulture Research Institute, Agriculture Research Center ARC, Egypt.
}

\begin{abstract}
This investigation was carried out at Antoniades Research Branch. Horticulture Institute, Ministry of Agriculture, Alexandria, Egypt, during 2016 and2017 seasons. The study was atrial to investigate the effects of pulsing benzyladenine (BA), gibberellic acid $\left(\mathrm{GA}_{3}\right)$ at $0.0,1.0,2.0$ and $3.0 \mathrm{mM}$ of each and salicylic acid (SA) at $0.0,0.5,1.0$ and $1.5 \mathrm{mM}$ on some vegetative and chemical trails during the vase life of Cyperus alternifolius stems. The results showed that application of benzyladenine (BA) at $2.0 \mathrm{mM}$ caused a significant increase in vase life, final water uptake, relative fresh weight (RFW),vase solution uptake rate (VSU ), chlorophyll $\mathrm{a}, \mathrm{b}$ and reducing sugar content.
\end{abstract}

Key words: Cyperus alternifolius, benzyladenine, gibberellic acid, salicylic acid.

\section{INTRODUCTION}

Cyperus alternifolius is a scientific name of umbrella sedge. It is a perennial aquatic herbthat grow in still or slow-moving water or humid soil. The plant also forms aesthetic appearances make it as an ornamental plant. It is cultivated in water gardens and at the margins of pools or ponds or as a pot plant. Moreover it is sold as a cut foliage in the flower markets (Kyambadde et al., 2004).

Plant growth regulators cause many effects on the postharvest quality of plants. These effects depend on plant species (Bosse and Van Staden,1989).External supply of cytokinins reduced the leaf chlorosis and yellowing in several cut foliage and flower species (Ranwala et al., 2003 and Singh et al., 2008). Pulsing shoots of Asparagus. setaceus in benzyladenine (BA) increased the vase life of 1.6 times higher than the control (Skutnik et al., 2006). Leaf yellowing in Alstroemeria was delayed by applying $\mathrm{GA}_{3}$ (Mutui et al., 2006). On the other hand, $\mathrm{GA}_{3}$ had no effect on vase life of Chrysanthemum (Doi and Reid, 1995).Salicylic acid (SA) has many diverse regularity roles in plant metabolism (Popova et al.,1997).It has many effects on cut foliage and flower species such as inhibition the upward gravitropic bending of snapdragon (Friedman et al, 2003), reduction of the vase solution $\mathrm{pH}$, decrement of the respiration rate, alleviation of the moisture stress, improving decorative quality and vase life of cut roses (Vahdati et al., 2012).

The present study was carried out to investigate the effects of $\mathrm{BA}, \mathrm{GA}_{3}$ and $\mathrm{SA}$ on cut foliage of Cyperus alternifoliusstems stems in order to identify the suitable postharvest treatments that would enhance its quality and longevity.

\section{MATERIALS AND METHODS}

The present study was carried-out at Antoniades Research Branch, Horticulture Research Institute, A.R.C. Alexandria, Egypt during the two successive seasons of 2016 and 2017.

A- Source of the cut stems

Stems of Cyperus plants were obtained from the Experimental Farm of Antoniades Research Branch.

\section{B-Chemicals used in the experiment}

1- Benzyladenine (BA) at concentrations of 0.0 , $1.0,2.0$ and $3.0 \mathrm{mM}$.

2- Gibberellic acid $\left(\mathrm{GA}_{3}\right)$ at concentrations of 0.0 , $1.0,2.0$ and $3.0 \mathrm{mM}$.

3- Salicylic acid (SA) at concentrations of $0.0,0.5$, 1.0 and $1.5 \mathrm{mM}$.

C-Cut stems preparations and treatments

On the $27^{\text {th }}$ October 2016 and $3^{\text {rd }}$ November 2017 (in the first and second seasons, respectively), cut stems were transported to the laboratory under dry conditions, they were recut before treatments to the length of $80 \mathrm{~cm}$ and pulsed in different concentrations of treatments for 24 hours. On the $28^{\text {th }}$ October 2016 and $4^{\text {th }}$ November 2017 (in the first and second seasons, respectively) pulsed stems were recut to $75 \mathrm{~cm}$ and put in glass jars (three stems per jar) containing distilled water $(750 \mathrm{ml} /$ jar) and the stems were remained in the lab.

Lab conditions: The average temperature of $18.6^{\circ}$ $19^{\circ}$, average humidity $(63 \%-65 \%)$ and 24 hours fluorescent light (500 lux).

D- Experimental layout and statistical analysis

The experimental layout was a randomized complete block design (RCBD) in factorial experiment. It consists of twelve treatments with three replicates, each treatment contains five cut stems. The means of the individual factors and their interactions were compared by L.S.D test at 5\% level of probability. The data were statistically 
analyzed according to the method described by Snedecor and Cochran (1989).

E- Data were recorded as the following

1-The postharvest characters

a- Vase life (days)

It was determined as the number of days from starting the experiment to the fading stage. The fading stage was set at the point when $30 \%$ of leaf bracts of the stem become yellow.

b- Loss of stem fresh weight percentage (L.F.F.W)

It was determined at the fading stage as the following formula (Tarek et al., 2013).

L.F.F.W. $(\%)=\frac{\text { Initial fresh weight }- \text { Final fresh weight }}{\text { Initial fresh weight }} \times 100$

c- Final water uptake (g)

It was calculated at the end of the experiment as the following formula (Soad et al., 2014)

Water uptake $(g)=$

The amount of the distelled water at the beginning of the experiment- the amount of the distelled water remaining at the end of the experiment.

d- Stem fresh weight / Stem dry weight ratio= Stem weight ratio (SWR):

At the fading stage the stems were oven dried at $75^{\circ} \mathrm{c}$ for 48 hours to get the stem dry weight (S.D.W.). SWR was calculated as follows. (Mahmoud, 2013).

SWR $=\frac{\text { Fresh weight per stem (g) }}{\text { Dry weight per stem (g) }}$

e- Relative fresh weight (RFW)

Fresh weight of the stems was determined just before the immersion of the stems into the distelled water and collected every three days until the vase life of the stems were terminated. The fresh weight of each stem was expressed relative to the initial weight to represent the water status of the stem $(\mathrm{He}$ et al., 2006).

Relative fresh weight $(\mathrm{RFW})=\frac{\text { Sw }}{\text { IFWo }} \times 100$

Calculated a sthe stem weight $\mathrm{Sw}(\mathrm{g})$ at $31^{\text {st }}$ October, $3^{\text {rd }}$ November and $6^{\text {th }}$ November in the first season and $7^{\text {th }}, 10^{\text {th }}$ and $13^{\text {th }}$ November in the second season based on $\mathrm{Sw}$ to the initial fresh weight of the same stem IFW0 (g)

f- Vase solution uptake rate (VSUR) \% (2009).

Was measured according to Damunupola

VSU rate $=\frac{(S t-1)-S t}{\text { IFW of stem }} \times 100$

Where (St ) is weight of distelled water $(\mathrm{g})$ at $31^{\text {st }}$ October, $3^{\text {rd }}$ November and $6^{\text {th }}$ November in the first season and $7^{\text {th }}, 10^{\text {th }}$ and $13^{\text {th }}$ November in the second season (St-1) is weight of the disstelled water $(\mathrm{g})$ on the previous day and (IFW) is the initial fresh weight $(\mathrm{g})$.

2- Chemical analysis

A-Chlorophyll a and b content (mg/ g fresh weight) was determined in leaves according to Moran (1982) at the end of vase life of control plant.
B-Reducing sugars content (mg/g dry weight) was determined according to Miller (1959) at the end of the experiment.

\section{RESULTS}

1-The postharvest characters:

a- Vase life (days):

Data presented in Table (1) showed that the longest significant vase life was obtained after application of BA treatments which were 13.13 and 12.71 days in the first and second seasons, respectively. Moreover, all chemical pulsing concentrations caused significant increase in vase life as compared to control plants. And the third concentration of BA gave the longest significant vase life in both seasons. There was a significant difference between the interaction of the used pulsing chemical and its concentrations and the longest significant vase life was obtained after pulsing Cyperus alternifoliusstems stems in Benzyladinenine at $2 \mathrm{~m}$ Mwhich were 18.00 and 16.67 days in the first and second season respectively.

b- Loss of flower fresh weight LFFW (\%)

Data in Table (1) cleared that there was a deferent in LFFW after application of any pulsing chemical. Application of SA treatments caused the highest decrease in LFFW (\%) in both seasons which were 28.60 and $31.10 \%$ in the first and second season, respectively. All used chemical concentrations caused significant decrease in LFFW as compared to control plants. Also, there was a significant different between the interaction of the used pulsing chemical and its concentrations, the untreated plants recorded the highest significant increase in LFFW \% in both seasons.

c- Final water uptake (g)

Data in Table (1) revealed that benzyladinenine treatments caused the highest significant increase in final water uptake in both seasons which were 123.7 and $170.01 \mathrm{~g} /$ plant in the first and second season. All used chemical concentrations caused significant increase in final water uptake as compared to control plants. Moreover, for the effect of the interaction of the used pulsing chemical and its concentrations the highest significant final water uptake was obtained after application of BA at $2.0 \mathrm{mM}$ which were (171.16 and $246.66 \mathrm{~g}$ ) in the first and second season respectively.

\section{d- Stem fresh weight/ stem dry weight ratio} (SWR)

Data in Table (1) indicated that pulsing Cyperus alternifolius stems in salicylic acid caused the highest significant increase in SWR which were 3.75 and 3.60 in the first and second season, respectively. 


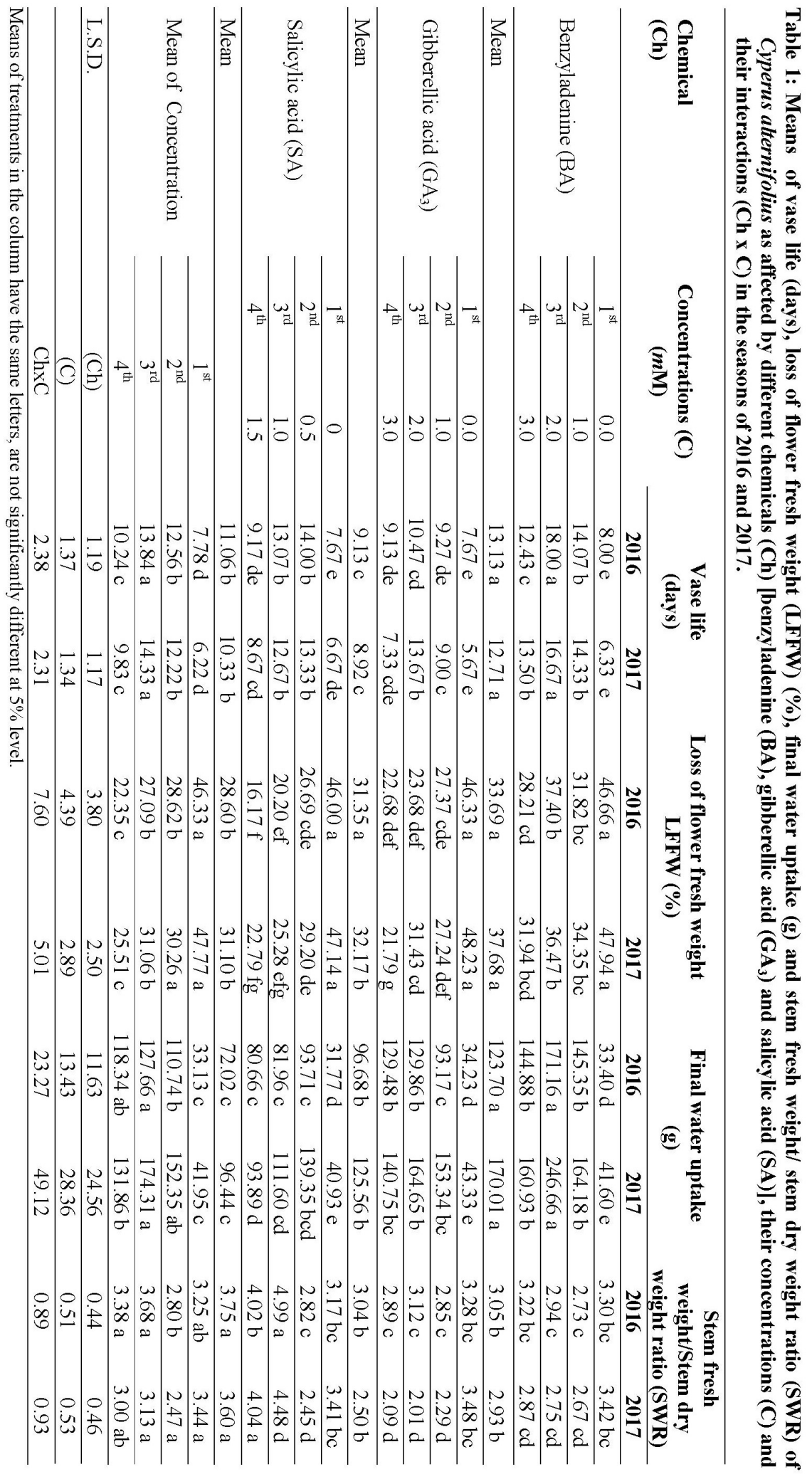


Also, data cleared that there was a significant different for the interaction of the used pulsing chemical and its concentrations and the highest SWR was obtained after application of SA at 1.0 $m \mathrm{M}$ which recorded 4.99 and 4.48 in the first and second season.

\section{e- Relative fresh weight RFW (\%)}

Figure (1) illustrated that for the season of 2016, after 3 days from the beginning of the experiment starting the value of RFW for all treatments was more than control plants. On $6^{\text {th }}$ day of the experiment starting the value of RFW for all treatments decreased, except BA treatments and SA at $0.5 \mathrm{mM}$ and the lowest RFW was obtained after control plants;. On the $9^{\text {th }}$ day of the experiment starting, the vase life of control plants was ended. Also, all RFW values dropped and the lowest drop was obtained after GA3 treatments.

For the season of 2017 , on the $3^{\text {rd }}$ day of the experiment start, RFW value for control plants was less than all treatments. While, after 6 days from the starting of the experiment was observed increment in the value of RFW for BA treatments and SA at $0.5 \mathrm{mM}$ as compared to their previous recorded values and the lowest RFW was recorded for untreated plants. On the $9^{\text {th }}$ day of the experiment starting the vase life of control plants was over, all treatments recorded decrement in the RFW value.

\section{f- Vase solution uptake rate VSUR (\%)}

Figure (2) cleared that in first and second seasons, control plants recorded the lowest VSUR value as compared to other treatments. More over, on the third recorded day after 9 days from the experiment starting the vase life of the control plants was terminated. On the $6^{\text {th }}$ day from the experiment starting the VSUR value for BA treatments and SA at $0.5 \mathrm{mM}$ was more than that recorded on the $3^{\text {rd }}$ day of experiment starting while, the other treatments recorded observed decrees in the VSUR value compared to the previous value recorded on the $3^{\text {rd }}$ day from the experiment starting. After 9 days from the experiment starting an obvious decrement in VSUR value for all treatments was recorded.

\section{2-The chemical characters}

\section{a- Chlorophyll a ( $\mathrm{mg} / \mathrm{g}$ fresh weight)}

Data in Table (2) cleared that the highest increase in chlorophyll a content was obtained after application of BA treatments which recorded 2.41and $1.98 \mathrm{mg} / \mathrm{g}$ fresh weight in the first and second season, respectively. All chemical concentrations caused a significant increase as compared to the control plants. For the interaction of the used pulsing chemical and its concentrations, the highest significant chlorophyll a content 5.43 and $3.21 \mathrm{mg} / \mathrm{g}$ fresh weight in the first and second season respectively was obtained after applying BA at $2 \mathrm{mM}$.

\section{b- Chlorophyll b (mg/g fresh weight)}

Data in Table (2) indicated that pulsing Cyperus stems in BA caused the highest significant increase in chlorophyll $\mathrm{b}$ content which recorded 0.71 and $0.58 \mathrm{mg} / \mathrm{g}$ fresh weight in the first and second season, respectively. Also, there was a significant different after application of different concentrations of pulsing chemical. For the interaction of the used pulsing chemical and its concentrations, the highest significant chlorophyll b content 1.84 and $1.10 \mathrm{mg} / \mathrm{g}$ fresh weight in the first and second season, respectively was recorded after applying BA at $2 \mathrm{mM}$.

\section{C- Reducing sugar (mg/g dry weight)}

Table (2) showed that the highest significant reducing sugar content was obtained after pulsing Cyperus stems in BA which recorded 7.24 and 7.35 $\mathrm{mg} / \mathrm{g}$ dry weight in the first and second season, respectively. Also, data cleared that the lowest significant reducing sugar content was obtained for untreated stems. For the interaction of the used pulsing chemical and its concentrations, pulsing Cyperus stems in BA at 1.0, 2.0 and SA at 0.5 caused the highest significant increase in reducing sugar content.

\section{DISCUSSION}

From the previous results it is observed that all treatments caused significant increase in the vase life of Cyperus alternifolius. The increase in vase life after application of benzyladenine (BA) may be attributed to its ability to maintain the integrity of the tonoplast membrane and preventing leakage of proteases which hydrolyse the soluble proteins of chloroplast and mitochondrial membranes (Thinmann, 1980). These results are in harmony with those obtained by Mariusz et al.(2006)who found that stomata aperture was higher about 44 $\%$ than control after application of BA in Hosta cut leaves. Also, the results cleared that salicylic acid (SA) treatments increased the vase life which may be due to the ability of SA in enhancement of chlorophyll content (Cevahir et al., 2005)and alsoincreased the antioxidant capacity of the cell which is probably the mechanism used to reduce the aging process in cut flowers (Ezhilmathi et al., 2007). The positive effect of gibberellic acidon vase life may be due to the ability of $\mathrm{GA}_{3}$ on delaying chlorophyll degradation and keeping stomata open. The effect of $\mathrm{GA}_{3}$ on increasing the vase life is in harmony with those obtained by Mariusz et al. (2006) where they found that stomata aperture was higher about $21 \%$ than control after application of $\mathrm{GA}_{3}$ in Zantedeschi a cut leaves. 

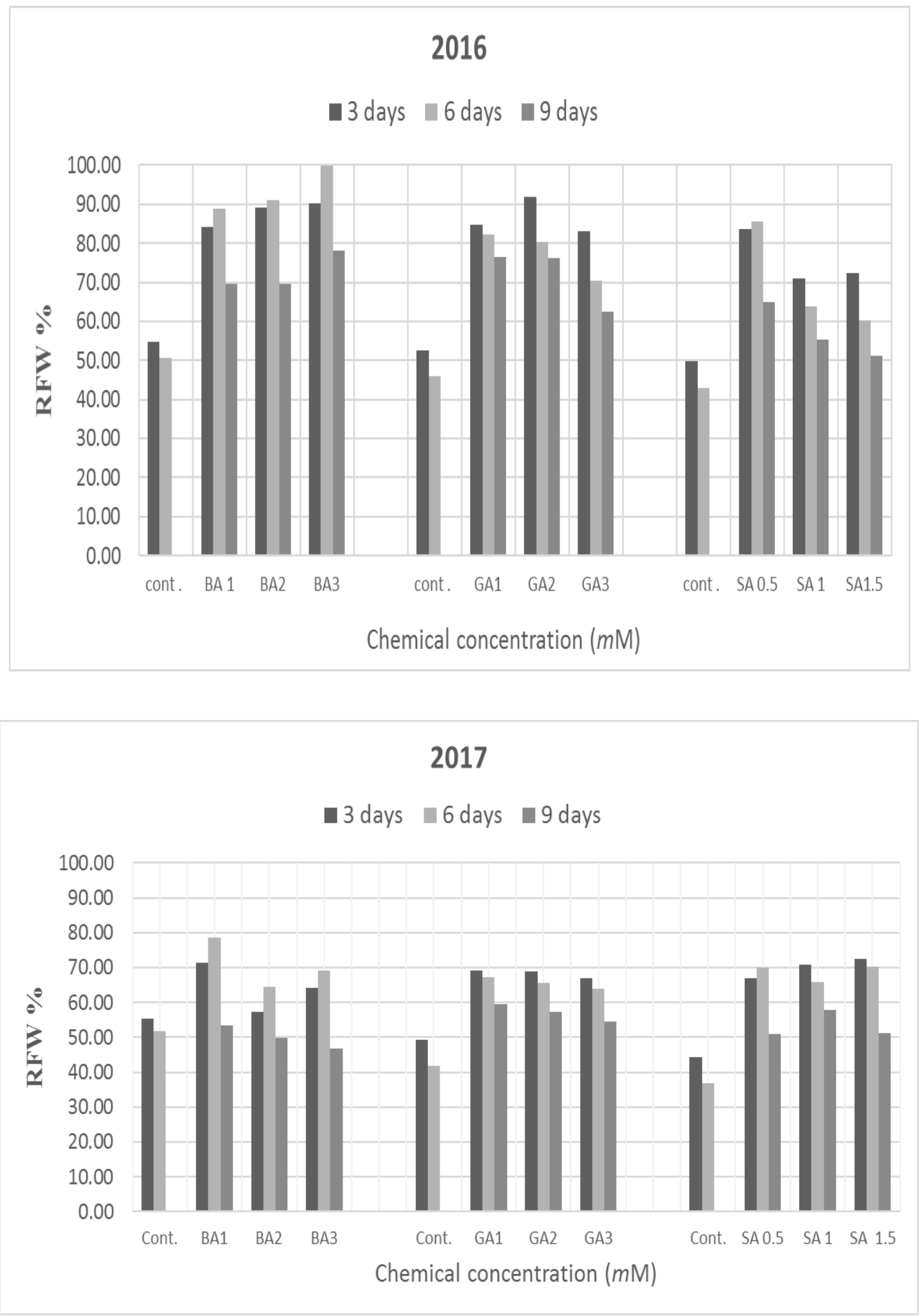

Figure 1: Effect of the interaction between the different chemicals and their concentrations on relative fresh weight (RFW \%) through the experiment period during the seasons of 2016 and 2017. 

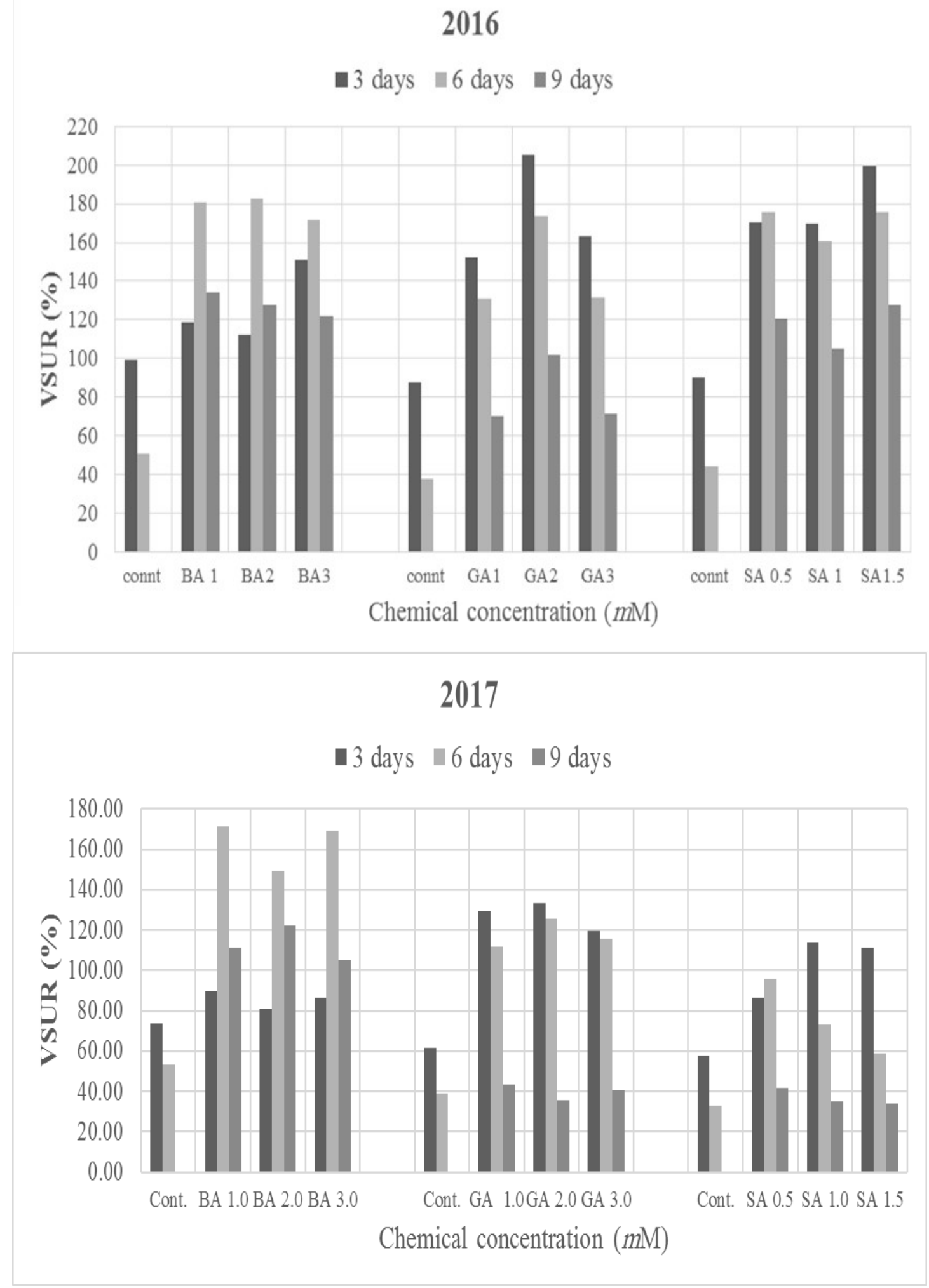

Figure 2: Effect of the interaction between the different chemicals and their concentrations on relative fresh weight (VSUR \%) through the experiment period during the seasons of 2016 and 2017. 
Table 2: Means of chlorophyll a (mg/g fresh weight), chlorophyll b (mg/g fresh weight) and reducing sugar (mg/g dry weight) of Cyperus alternifolius as affected by different chemicals (Ch) [benzyladenine (BA), gibberellic acid $\left(\mathrm{GA}_{3}\right)$ and salicylic acid $(\mathrm{SA})$ ], their concentrations $(\mathrm{C})$ and the interactions $(\mathrm{Ch} \times \mathrm{C})$ in the seasons of 2016 and 2017.

\begin{tabular}{|c|c|c|c|c|c|c|c|c|}
\hline \multirow{2}{*}{$\begin{array}{l}\text { Chemical } \\
\text { (Ch) }\end{array}$} & \multirow{2}{*}{\multicolumn{2}{|c|}{$\begin{array}{c}\text { Concentrations }(\mathrm{C}) \\
\qquad(m \mathrm{M})\end{array}$}} & \multicolumn{2}{|c|}{$\begin{array}{c}\text { Chlorophyll a } \\
\text { (mg/g fresh weight) }\end{array}$} & \multicolumn{2}{|c|}{$\begin{array}{c}\text { Chlorophyll b } \\
\text { (mg/g fresh weight) }\end{array}$} & \multicolumn{2}{|c|}{$\begin{array}{l}\text { Reducing sugar } \\
\text { (mg/g dry weight) }\end{array}$} \\
\hline & & & 2016 & 2017 & 2016 & 2017 & 2016 & 2017 \\
\hline \multirow{4}{*}{$\begin{array}{l}\text { Benzyladenine } \\
\text { (BA) }\end{array}$} & $1^{\text {st }}$ & 0.0 & $0.96 \mathrm{~b}$ & $0.85 \mathrm{f}$ & $0.18 \mathrm{c}$ & $0.13 \mathrm{e}$ & $2.88 \mathrm{f}$ & $3.42 \mathrm{c}$ \\
\hline & $2^{\text {nd }}$ & 1.0 & $2.12 \mathrm{~b}$ & $2.46 \mathrm{~b}$ & $0.49 \mathrm{bc}$ & $0.74 \mathrm{~b}$ & $8.72 \mathrm{ab}$ & $8.94 \mathrm{a}$ \\
\hline & $3^{\text {rd }}$ & 2.0 & $5.43 \mathrm{a}$ & $3.21 \mathrm{a}$ & $1.84 \mathrm{a}$ & $1.10 \mathrm{a}$ & $9.49 \mathrm{a}$ & $10.03 \mathrm{a}$ \\
\hline & $4^{\text {th }}$ & 3.0 & $1.12 \mathrm{~b}$ & $1.40 \mathrm{def}$ & $0.30 \mathrm{bc}$ & 0.34 cde & $7.86 \mathrm{bc}$ & $6.99 \mathrm{~b}$ \\
\hline Mean & & & $2.41 \mathrm{a}$ & $1.98 \mathrm{a}$ & $0.71 \mathrm{a}$ & $0.58 \mathrm{a}$ & $7.24 \mathrm{a}$ & $7.35 \mathrm{a}$ \\
\hline \multirow{4}{*}{$\begin{array}{l}\text { Gibberellic acid } \\
\qquad\left(\mathrm{GA}_{3}\right)\end{array}$} & $1^{\text {st }}$ & 0.0 & $0.85 \mathrm{~b}$ & $0.94 \mathrm{ef}$ & $0.22 \mathrm{bc}$ & $0.16 \mathrm{e}$ & $2.83 \mathrm{f}$ & $3.52 \mathrm{c}$ \\
\hline & $2^{\text {nd }}$ & 1.0 & $1.31 \mathrm{~b}$ & $1.56 \mathrm{cdef}$ & $0.39 \mathrm{bc}$ & $0.25 \mathrm{de}$ & $4.72 \mathrm{e}$ & $4.50 \mathrm{c}$ \\
\hline & $3^{\text {rd }}$ & 2.0 & $2.17 \mathrm{~b}$ & $2.09 \mathrm{bc}$ & $0.51 \mathrm{bc}$ & $0.52 \mathrm{bc}$ & $5.37 \mathrm{de}$ & $4.07 \mathrm{c}$ \\
\hline & $4^{\text {th }}$ & 3.0 & $1.05 \mathrm{~b}$ & $1.92 \mathrm{bcd}$ & $0.31 \mathrm{bc}$ & $0.42 \mathrm{~cd}$ & $5.04 \mathrm{e}$ & $4.72 \mathrm{c}$ \\
\hline Mean & & & $1.35 \mathrm{~b}$ & $1.63 \mathrm{~b}$ & $0.36 \mathrm{~b}$ & $0.34 \mathrm{~b}$ & $4.49 \mathrm{c}$ & $4.20 \mathrm{c}$ \\
\hline \multirow{4}{*}{$\begin{array}{l}\text { Salicylic acid } \\
\text { (SA) }\end{array}$} & $1^{\text {st }}$ & 0 & $0.99 \mathrm{~b}$ & $0.89 \mathrm{f}$ & $0.21 \mathrm{bc}$ & $0.13 \mathrm{e}$ & $2.94 \mathrm{f}$ & $3.46 \mathrm{c}$ \\
\hline & $2^{\text {nd }}$ & 0.5 & $2.21 \mathrm{~b}$ & $2.46 \mathrm{~b}$ & $0.54 \mathrm{bc}$ & $0.74 \mathrm{~b}$ & $9.16 \mathrm{ab}$ & $9.7 \mathrm{a}$ \\
\hline & $3^{\text {rd }}$ & 1.0 & $1.28 \mathrm{~b}$ & $1.34 \mathrm{def}$ & $0.29 \mathrm{bc}$ & $0.34 \mathrm{cde}$ & $6.56 \mathrm{~cd}$ & $6.56 \mathrm{~b}$ \\
\hline & $4^{\text {th }}$ & 1.5 & $1.24 \mathrm{~b}$ & $1.38 \mathrm{def}$ & $0.32 \mathrm{bc}$ & $0.45 \mathrm{~cd}$ & $4.72 \mathrm{e}$ & $4.72 \mathrm{c}$ \\
\hline Mean & & & $1.43 \mathrm{~b}$ & $1.52 \mathrm{~b}$ & $0.34 \mathrm{~b}$ & $0.42 \mathrm{~b}$ & $5.84 \mathrm{~b}$ & $6.11 \mathrm{~b}$ \\
\hline \multirow{4}{*}{$\begin{array}{l}\text { Mean of } \\
\text { Concentration }\end{array}$} & \multicolumn{2}{|c|}{$1^{\text {st }}$} & $0.93 \mathrm{c}$ & $0.89 \mathrm{c}$ & $0.20 \mathrm{c}$ & $0.14 \mathrm{c}$ & $2.88 \mathrm{c}$ & $3.47 \mathrm{c}$ \\
\hline & \multicolumn{2}{|c|}{$2^{\text {nd }}$} & $1.88 \mathrm{~b}$ & $2.16 \mathrm{a}$ & $0.47 \mathrm{~b}$ & $0.58 \mathrm{a}$ & $7.54 \mathrm{a}$ & $7.71 \mathrm{a}$ \\
\hline & \multicolumn{2}{|c|}{$3^{\text {rd }}$} & $2.96 \mathrm{a}$ & $2.21 \mathrm{a}$ & $0.88 \mathrm{a}$ & $0.68 \mathrm{a}$ & $7.14 \mathrm{a}$ & $6.88 \mathrm{a}$ \\
\hline & \multicolumn{2}{|c|}{$4^{\text {th }}$} & $1.13 \mathrm{bc}$ & $1.57 \mathrm{~b}$ & $0.31 \mathrm{bc}$ & $0.40 \mathrm{~b}$ & $5.87 \mathrm{~b}$ & $5.48 \mathrm{~b}$ \\
\hline \multirow[t]{3}{*}{ L.S.D. } & \multicolumn{2}{|c|}{$(\mathrm{Ch})$} & 0.76 & 0.34 & 0.18 & 0.12 & 0.71 & 0.81 \\
\hline & \multicolumn{2}{|c|}{ (C) } & 0.88 & 0.39 & 0.21 & 0.14 & 0.82 & 0.93 \\
\hline & \multicolumn{2}{|c|}{ ChxC } & 1.53 & 0.67 & 0.36 & 0.24 & 1.42 & 1.62 \\
\hline
\end{tabular}

Means of treatments in the column have the same letters, are not significantly different at $5 \%$ level

The lowest significant final water uptake, SWR values and highest significant LFFW were obtained from the distilled water treatment which may explain the lowest vase life of the control flowers.

When flowers are cut from the plant, water loss continues through transpiration. The perfect flower preservative is that which allows water absorption in flower tissues or water absorption from the preservative solution maintains a better water balance and flower which enhancing vase-life. (Salunkhe et al., 1990). Our study cleared that RFW values of the BA treatments and SA at $0.5 \mathrm{mM}$ had high value along the experiment period which may illustrate the freshness of stems and longevity after these treatments. Also, it has been noticed that the high value of VSUR on the second measuring date explains the freshness and flower longevity of Cyperus stems from BA treatments and SA at 0.5 $m \mathrm{M}$.

The highest significant decrease in chlorophyll $\mathrm{a}$ and $\mathrm{b}$ degradation after application of BA at 2.0 $\mathrm{mM}$ can be explained according by Mutui et al.(2001) who mentioned that cytokinins treatment delaying leaf senescence and improve the keeping quality of many cut flowers. Also, Sallsbury and Ross (1996) have reported that cytokinins promote chloroplast development and chlorophyll synthesis. Also, all the treatments led to a significant increase in reducing sugar content and this increment may increase the osmotic potential of the flowers, thus improving their ability to absorb nutrients and maintain their turgidity, which may explain the increase of flower longevity in different treatments in this study (Prathamesh and John 2013).

Finally it could be recommended in the case of Cyperus alternifolius cut stems, using benzyladinenine at $2.0 \mathrm{mM}$ as a pulsing treatment for 24 hours which resulted in highest vase life, final water uptake, chlorophyll $\mathrm{a}$ and $\mathrm{b}$ and reducing sugar content.

\section{REFERENCES}

Bosse, A. and J. Van Staden, (1989). Cytokinins in cut carnation flowers. Effect of cytokinin type, and mode of application on flower longevity. J. of Plant Physio. 135: 155-159. 
Cevahir, G., S. Yentur and N. Yilmaze. (2005). The effect of nitric oxide, salicylic acid and hydrogen peroxide on the pigment content in excited cotyledons of red cabbage'. Freschius Env. Bulletin, 14: 591-598.

Damunupola, J.W. (2009). Xylem flow in cut Acacia holosericea stems. Ph.D. Thesis. University of Queensland, Queensland, Australia.

Doi, M. and Reid, M.S. (1995). Sugar improves the postharvest life of cut flowers of hybrid Limonium. Hort. Sci. 30: 1058-1060.

Ezhilmathi, K., V. Singh, P. Arora, R. K. Sairam. (2007). 'Effect of 5-sulfocalicylic acid on antioxidant in relation to vase life of gladiolus cut flower'. Plant Growth Regul, 51: 99-108.

Friedman, H, JW. Vos , PK Hepler, S. Meir, AH Halevy and AH Sonia (2003). The role of actin filaments in the gravitropic response of snapdragon flowering shoots. Planta 216(6): 1034-1042.

He, S.G., D.C. Joyce, D.E. Irving and J.D. Faragher. (2006). Stem end blockage in cut Grevilla 'Crimson Yul-lo' inflorescences. Postharvest Biol. and Techn., 41: 78-84.

Kyambadde, J., F. Kansiime, L. Gumaelius, and G. Dalhammar, (2004). A comparative study of Cyperus papyrus and Miscanthidium violaceum based constructed wetlands for wastewater treatment in a tropical climate. Water Research, 38(2): 475-485.

Mahmoud, A.E.K. (2013). Vegetable plants physiology. El-Maaref Publishers Alexandria. P.302

Mariusz, W., E. Skutnik and J. Rabiza-Świder (2006). The effect of growth regulators on stomatal aperture in senescing cut leaves of Zantedeschia aethiopica Spr. and Hosta Tratt. 'Undulata Erromena' Folia Hortic., 18 (2): 6575.

Miller, G.L. (1959). Use of dinitrosalicylic acid reagent for determination of reducing sugar Anal. Chem., 31 (3): 426-428.

Moran, R. (1982). Formula for determination of chlorophyll pigment extracted with N,N diethyl formamide. Plant Physio., 69: 13761381

Mutui, TM, WE. Emongor and MJ. Hutchinson (2001). Effect of Accel on the vase life and postharvest quality of Alstromeria cut flowers. Afric. J. Sci. Thecnol., 2: 82-88.
Mutui, TM, WE. Emongor and MJ. Hutchinson (2006). The effects of gibberellins ${ }_{(4+7)}$ on the vase life and flower quality of Alstroemeria cut flowers. Plant Growth Regul., 48: 207-214.

Popova, L., T. Pancheva and U. Alexandra (1997). Salicylic acid: properties, biosynthesis and physiological role. Bulg. J. Plant Physiol., 23(1-2): 85-93.

Prathamesh, V. and P.C. John (2013) .Effect of biocides and sucrose on vase life and quality of cut gerbera Gerbera jamesonii cv. Maron Dementine. HortFlora Res.Spectrum, 2(3): 239-243.

Ranwala, A.P., G. Legnani G. and W. B. Miller (2003). Minimizing stem elongation during spray application of gibberellins $(4+7)+$ benzyladenine to prevent leaf chlorosis in Easter lily. Hort. Sci., 38: 1210-1213

Sallsbury, F. and C.W. Ross (1996). Plant physiology. $6^{\text {th }}$ End. Wadworth, California.: 274-277.

Salunkhe, D.K., N. R. Bhat and B.B. Desai (1990). "Post-Harvest Biotechnology of Flowers and Ornamental Plants", Springer- Verlag, Berlin.

Singh, A., J. Kumar, and P. Kumar. (2008). Effect of plant growth regulators and sucrose on postharvest physiology, membrane stability and vase life of cut spikes of gladiolus. Plant Growth Regul., 55: 221-229.

Skutnik, E., J. Rabiza-Świder and J. Aleksandra (2006). Evaluation of several chemical agents for prolonging vase life in cut Asparagus greens .J. Fruit Ornam. Plant Res. 14: 233-240.

Snedecor, G. W. and W. Cochran. (1989), Statistical Methods, Eighth Edition, Iowa State University Press.

Soad A. M. Khenizy, M.A. Azza and H.A. Gehan ( 2014). Effect of natural extracts on vase life of gypsophila cut flowers. Scientific J. Flowers \& Ornamental Plants, 1(1):1-16 .

Tarek A.M., F.Y.E. Amira., A.M.K. Soad and F.M.E. Eman (2013). Impact of various pulsing and holding solutions on the quality and longevity of Nephrolepis exaltata (L.) Schott cut foliage under room temperature $\mathrm{J}$. Hort. Sci. and Ornamen. Plants., 5 (2): 89-99.

Thinmann, K.V. (1980). The senescence of leaves. Thinmann K.V. (Ed.), Senescence in Plants. CRC Press, Boca Raton, Florida.

Vahdati, N.M., A. Tehranifar A., H. Bayat, and Y. Selahvarzi (2012). Salicylic and citric acid treatments improve the vase life of cut chrysanthemum flowers.J. Agr. Sci. Tech. 14: 879-887. 


\section{الملخص العربي}

تأثير بعض المركبات المضاده للشيخوخه على الجودة والقدة الحفظية لسيقان نبات البردي

$$
\begin{aligned}
& \text { رحاب أحمد صفار ، أسماء محمد طه } \\
& \text { فرع بحوث نباتات الزينة بأنطونيادس- الإسكندرية - معهد بحوث البساتين- مركز البحوث الزر اعية ميكاء }
\end{aligned}
$$

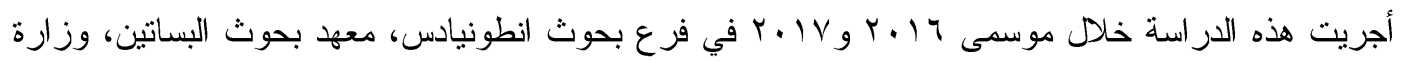

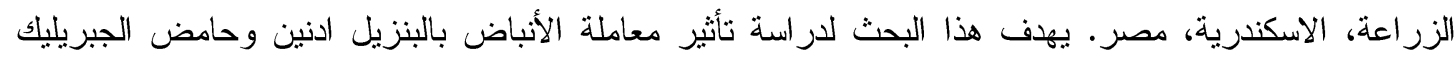

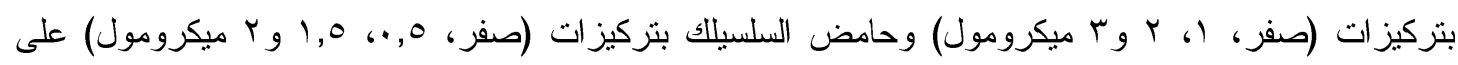

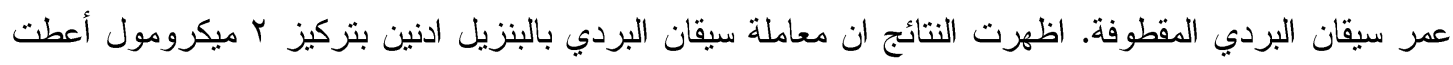

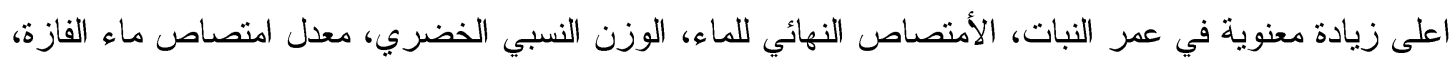
كلورفيل أ، ب ومحتوى النبات من السكريات المختزلة. 